\title{
Community Perception to Reduce Safe Drinking Water Scarcity A Case Study at Debishing Para In Rajshahi City Corporation Area, Bangladesh
}

\author{
Lamia Ferdous*, Sabrina Sharmin, Md Nahidul Islam and Nazia Hossain \\ Department of Urban \& Regional Planning, Rajshahi University of Engineering \& Technology (RUET), Bangladesh
}

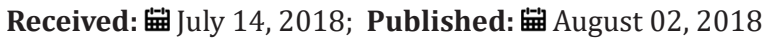

*Corresponding author: Lamia Ferdous, Undergrad student, Department of Urban \& Regional Planning, Rajshahi University of Engineering \& Technology (RUET), Rajshahi-6204, Bangladesh

\begin{abstract}
The safe drinking water crisis is recognized as one of the major problems and the significant barrier to improve health and wellbeing in Rajshahi city. Basically, RWASA (Rajshahi Water Supply and Sewerage Authority) supplies water at Debishingpara in Rajshahi City Corporation (RCC). Safe drinking water crisis is becoming intensified day by day in Rajshahi City. The objective of the study is to identify local problem regarding safe drinking water scarcity in the community and to propose a communitybased Strategies for reducing safe drinking water crisis. Participatory Rural Appraisal (PRA) approach was applied to identify the problems and suggest the community- based solution by involving community people. The study has been conducted by collecting data from a focus group which consists of 8 members ( 4 males and 4 females) on supplied water and water collection system. Causeeffect diagram and Pair-wise Ranking Matrix was used as PRA tools to understand the causes and impact of drinking water scarcity and identify the main difficulties to access safe drinking water. According to the focus group discussion, the community people suffered mostly due to lack of water purification system, less number of tube well and existence of iron in the water. The study includes a dream map which obtains suggestions from the participants of the focus group. This study emphasizes on the community participation in the participatory forum to discuss appropriate solutions relating to the supplied water in the community. This study also tries to incorporate relevant policy and strategy to improve the condition.
\end{abstract}

Keywords: Safe drinking water; Water crisis; Community based approach; Participatory Rural Appraisal (PRA)

\section{Introduction}

Bangladesh has one of the highest population densities in the world, with a population of 160 million living within 57,000 square miles. Of those 160 million people, 13 percent lack safe water and 39 percent lack improved sanitation (Bangladesh's water and sanitation crisis,2017) [1]. The sources of water in Bangladesh are surface water, groundwater and rainwater. Of them Groundwater is available in adequate quantity, but the availability of groundwater for drinking purposes has become a problem for the following reasons- arsenic in groundwater, excessive dissolved iron, salinity in the shallow aquifers in the coastal areas, lowering of groundwater level, rock/stony layers in hilly areas. Rajshahi District (Zila), which covers an area of $2407 \mathrm{~km}^{2}$, of which $62 \mathrm{~km}^{2}$ is river, is located in the north west of Bangladesh bordering India to the south (BBS 1993) [2]. Within the Rajshai City Corporation
(RCC) area there exist several water bodies covering $2.3 \mathrm{~km}^{2}(5 \%$ of the total land area). These water bodies are used for various purposes including bathing; disposal of wastewater; and irrigation of some of the $14.8 \mathrm{~km}^{2}$ of agricultural and horticultural land that is located within the RCC area. In Rajshani, (93\%) of households relying on tube-well water for their drinking purposes. This is the case in both rural and urban areas although in urban areas some $8 \%$ of households have piped water supplies compared to less than $1 \%$ in rural areas. Tube-well use has

increased at the expense of wells, ponds and other sources (BBS 2005b) [3]. In Rajshahi City there are 785 community water stand-posts, 85 on-street water stands, eight overhead tanks and three water treatment works. The RCC has provided around 20000 water supply connections from 45 pumps. In addition to 
this Rajshahi University, Rajshahi Medical College, RDA and some other organizations have their own water supplies (RDA voll 2004, p. 38) $[4,5]$. Ground water pollution has been found to be a critical problem in Rajshahi City and the surrounding areas. The main problems relate to the high iron content, which is in the range 0.43.5mg l -1 in the RCC area ad 0.23-7.12mg l-1 outside the RCC area, both of which exceed the national drinking water standards for iron of 0.3-1.0mg l -1 (RDA vol-I 2004, p. 29; GoB 1997). The level of manganese was also found to be high, ranging from $0.1-1.52 \mathrm{mg} \mathrm{l}-1$ in the RCC area to $0.23-2.40 \mathrm{mg} \mathrm{l}-1$ outside the area, and exceeding the drinking water standard of $0.1 \mathrm{mg} \mathrm{l}-1$ (RDA vol-I 2004, p. 29; GoB 1997). With the increase of population demand for the safe drinking water is increasing as well. Further, human intervention increasing this crisis making water sources polluted and unusable. Water crisis is one of the major problems in modern urban area. But the problem is acute in Rajshahi city. Because of the geographic location of the Rajshahi city the soil condition is not suitable for sinking tube- well. The layer of water is in very lower level. The study area has been chosen for exploring the safe drinking water crisis is "Debishingpara" which belongs to ward no 27.

\section{Objectives and Methodology of the Study}

The specific objective of the study is to identify local problem regarding safe drinking water scarcity in the community. The study also aims to propose a community-based approach for reducing safe drinking water crisis. For this study, Participatory Rural Appraisal (PRA) method has been used. A focus group was formed which consists of eight (8) members ( 4 males and 4 females). The members of focus group have participated directly to identify the problems and suggest the community- based solution. Three PRA tools have been applied- Cause effect diagram, Pair-wise ranking matrix \& Dream map. Cause effect diagram was used for understanding the causes and impacts of drinking water scarcity. Pair-wise matrix was used for identifying the main difficulties to access safe drinking water among several problems in the study area through ranking process. Finally, a dream map was used for obtaining suggestions in the way they thinking to solve the problems. Through dream map they can easily visualize and find ways to achieve the desired dream.

\section{Study Area Profile}

In Debishing para, the major land use is residential use. The selected study area belongs to ward no 27 of Rajshahi City Corporation (RCC) area. The selected study area is Debishingpara. There is also some commercial and mixed land use. In Debishing para, the residential settlement was started 33 years before in 1984 . According to the local people now there is living approximately 12000 Households at 2500 settlements in the community. The average household size of the community is 5 persons per household.

It is found that the land use of the study area includes 3 kindergarten and technical school.1 dental care 2 mosque 10 grossary shop and 1 pond. Though there was 3 pond in the past but 2 of them are fill up for commercial and residential purpose (Figure 1).

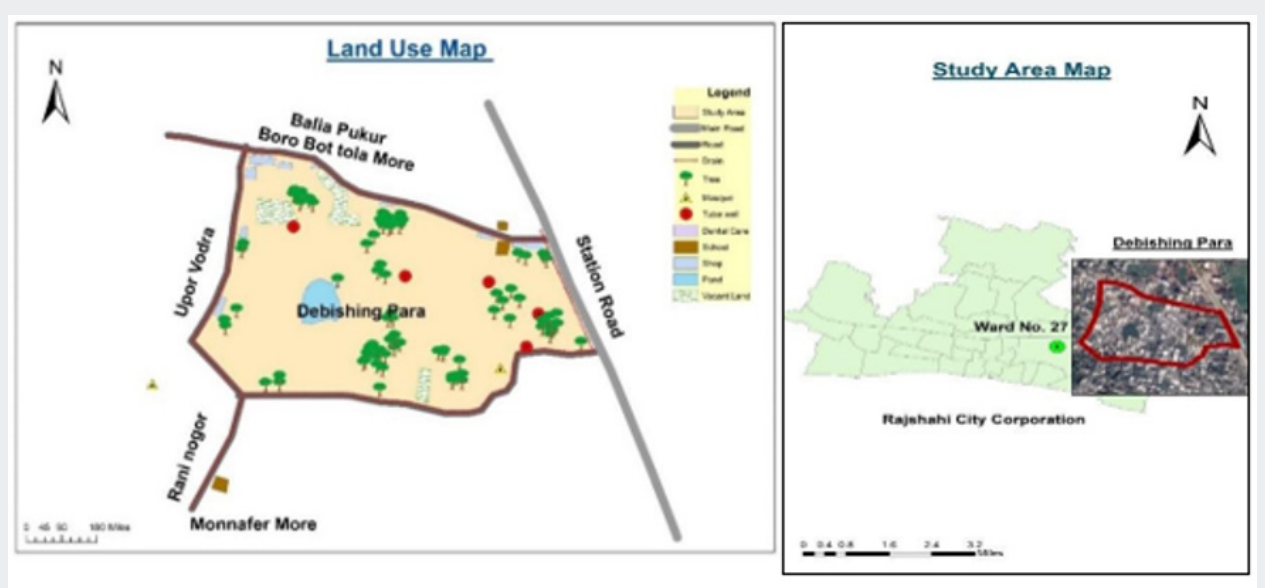

(a)

(b)

Figure 1: Study Area Map (a) and Land use map (b) of the study area.

\section{Results and Discussion}

\section{Problem identification ranking along with cause and effect of the problems}

Problems regarding drinking water scarcity in the study area: In the study area, there is a few number of water sources that serve the whole community. People are facing problems in collecting water because they have to wait a long time to collect water as there is only three tube- wells in their locality. The accessibility is not good at all, because the roads are too narrow to access the tube- wells. People are facing problems in collecting water from those water sources because it is difficult to carry out the water pot through the narrow road.

Causes and effects of the problems: The first problem was having no dustbin in the area. Basically, this is because of lack of sincerity of Rajshahi City Corporation. Again, there is lack of space 
to establish dustbin in the area. This problem results in frequent waste dumping on the roadside and this also creates problem while collecting the waste. Main problem of the area is lack of safe drinking water. The causes behind the problem are less number of tube well, existence of iron in the area, lack of water purification system, high elevated land, and ground water depletion in the area, narrow road and high population density. The effect of the problems is mainly worsening health condition due to lack of safe drinking water, less water accessibility, people are wasting time to collect water, obstruction in daily life, overcrowd water collection point during peak hour, less safety of women in the water collection point, causing pressure in the existing tube well and finally financial problem (Figure 2).

\begin{tabular}{|c|c|c|c|c|c|c|c|c|}
\hline Effect & $\begin{array}{l}\text { Worseni } \\
\text { ng } \\
\text { health } \\
\text { conditio } \\
\text { n due to } \\
\text { lack of } \\
\text { safe } \\
\text { drinking } \\
\text { water }\end{array}$ & $\begin{array}{l}\text { Less } \\
\text { water } \\
\text { access } \\
\text { ibility }\end{array}$ & $\begin{array}{l}\text { People } \\
\text { are } \\
\text { wasting } \\
\text { time to } \\
\text { collect } \\
\text { water. }\end{array}$ & $\begin{array}{l}\text { Obstruct } \\
\text { ion in } \\
\text { daily life }\end{array}$ & $\begin{array}{l}\text { Overcrow } \\
\text { d water } \\
\text { collection } \\
\text { point } \\
\text { during } \\
\text { peak hour. }\end{array}$ & $\begin{array}{l}\text { Less } \\
\text { safety of } \\
\text { women } \\
\text { in the } \\
\text { water } \\
\text { collectio } \\
\text { n point }\end{array}$ & $\begin{array}{l}\text { Causing } \\
\text { pressure } \\
\text { in the } \\
\text { existing } \\
\text { tube } \\
\text { well }\end{array}$ & $\begin{array}{l}\text { Financial } \\
\text { problem }\end{array}$ \\
\hline Problem & \multicolumn{8}{|c|}{ Lack of Safe Drinking Water } \\
\hline Cause & $\begin{array}{l}\text { Less } \\
\text { number } \\
\text { of tube } \\
\text { well }\end{array}$ & & $\begin{array}{l}\text { Lack } \\
\text { purific } \\
\text { system }\end{array}$ & $\begin{array}{l}\text { of water } \\
\text { tion }\end{array}$ & $\begin{array}{l}\text { High } \\
\text { elevated } \\
\text { land }\end{array}$ & $\begin{array}{l}\text { Ground } \\
\text { water } \\
\text { depletion } \\
\text { in the area. }\end{array}$ & $\begin{array}{l}\text { Narrow } \\
\text { road }\end{array}$ & $\begin{array}{l}\text { High } \\
\text { population } \\
\text { density }\end{array}$ \\
\hline
\end{tabular}

Figure 2: Cause-effect diagram.

Prioritizing the problems with pair-wise ranking matrix: Pair wise ranking is often used by social scientists, and increasingly by community development workers, as a means of prioritizing or ranking lists prepared by communities. In pair-wise ranking method two items, attributes, factors, etc., are compared at a time. This process of comparing two at a time is carried on till each item

Table 1: Pair Wise Ranking Matrix. has been compared with other (Rock, F., ed). In this case, according to survey most of the participants have claimed that there are various problems in the supplied water in the study area. Pair-wise ranking matrix shows the priority wise ranking of the problems in the study zone (Table 1).

\begin{tabular}{|c|c|c|c|c|c|c|c|c|c|}
\hline Problems & $\begin{array}{l}\text { Less } \\
\text { number of } \\
\text { tubes well } \\
\text { (a) }\end{array}$ & $\begin{array}{l}\text { Existence } \\
\text { of iron in } \\
\text { water (b) }\end{array}$ & $\begin{array}{c}\text { Lack of } \\
\text { Water } \\
\text { purification } \\
\text { system (c) }\end{array}$ & $\begin{array}{c}\text { High } \\
\text { elevated } \\
\text { land (d) }\end{array}$ & $\begin{array}{l}\text { Ground water } \\
\text { depletion in } \\
\text { the area (e) }\end{array}$ & $\begin{array}{l}\text { Narrow } \\
\text { road (f) }\end{array}$ & $\begin{array}{c}\text { High } \\
\text { population } \\
\text { density (g) }\end{array}$ & Frequency & Ranking \\
\hline $\begin{array}{l}\text { Less number } \\
\text { of tube, well } \\
\text { (a) }\end{array}$ & $\mathrm{X}$ & a & c & a & a & a & a & 5 & $2^{\text {nd }}$ \\
\hline $\begin{array}{l}\text { Existence of } \\
\text { iron in water } \\
\text { (b) }\end{array}$ & a & $\mathrm{X}$ & c & d & $\mathrm{b}$ & $\mathrm{b}$ & $\mathrm{b}$ & 4 & $3^{\text {rd }}$ \\
\hline $\begin{array}{l}\text { Lack of } \\
\text { Water } \\
\text { purification } \\
\text { system (c) }\end{array}$ & c & c & $\mathrm{X}$ & c & c & c & c & 6 & $1^{\text {st }}$ \\
\hline $\begin{array}{l}\text { High } \\
\text { elevated } \\
\text { land (d) }\end{array}$ & a & $d$ & c & $\mathrm{X}$ & d & $\mathrm{f}$ & d & 3 & $4^{\text {th }}$ \\
\hline $\begin{array}{c}\text { Ground } \\
\text { water } \\
\text { depletion in } \\
\text { the area } €\end{array}$ & a & $\mathrm{b}$ & c & d & $\mathrm{X}$ & $\mathrm{f}$ & e & 0 & $5^{\text {th }}$ \\
\hline
\end{tabular}




\begin{tabular}{|c|c|c|c|c|c|c|c|c|}
\hline $\begin{array}{c}\text { Narrow road } \\
\text { (f) }\end{array}$ & a & b & c & f & f & X & f & 3 \\
\hline $\begin{array}{c}\text { High } \\
\text { population } \\
\text { density (g) }\end{array}$ & a & b & c & d & e & f & X & 0 \\
\hline
\end{tabular}

In order to find the overall picture of the problems in the locality, the participants were asked to identify the problems related to safe drinking water crisis in that area. About seven problems have been identified which are faced by the local peoples in their daily life. The problems which are identified are- less number of tube well, existence of iron in water, lack of water purification system, high elevated land, and ground water depletion in the area, narrow road, and high population density (Table 1). After identification of the problems, each of the problems has been compared with one another and an overall ranking of the problems has been developed with the help of the participants. The problems and the ranking based on the frequency are then summarized in a pair wise matrix for better understanding. The ranking of the problems is as follows:

a) Problem 01: Lack of water purification system.

b) Problem 02: Less number of tube well.

c) Problem 03: Existence of iron in water.

The reason and following impacts of the ranked problems are also shown in (Figure 3). According to the pair wise ranking the following three problems are detected:

\begin{tabular}{|c|c|c|}
\hline Effect & Unable in domestic uses & Worsening health condition \\
\hline Problem & \multicolumn{2}{|c|}{ Lack of Water Purification system } \\
\hline Cause & Financial problem & Lack of awareness \\
\hline
\end{tabular}

Cause Effect Diagram; Problem: 01

\begin{tabular}{|l|l|l|l|l|}
\hline Effect & $\begin{array}{l}\text { Pressure in safe } \\
\text { drinking } \\
\text { collection }\end{array}$ & $\begin{array}{l}\text { Overcrowded water } \\
\text { wallection point in the } \\
\text { peak hour }\end{array}$ & High water demand & $\begin{array}{l}\text { Less security to } \\
\text { collect water }\end{array}$ \\
\hline \multicolumn{5}{|c|}{ Less number of tube-well } \\
\hline Problem & \multicolumn{5}{|c|}{$\begin{array}{l}\text { Problem in sinking tube- } \\
\text { well }\end{array}$} & High elevation of land & $\begin{array}{l}\text { Existence of } \\
\text { unused tube- } \\
\text { well }\end{array}$ \\
\hline Cause & Financial problem & $\begin{array}{l}\text { of } \\
\text { tul }\end{array}$
\end{tabular}

\begin{tabular}{|c|l|l|l|l|}
\hline \multicolumn{5}{|c|}{ Cause Effect Diagram; Problem: 02 } \\
\hline Effect & $\begin{array}{l}\text { Unpleasant odor, taste } \\
\text { and color }\end{array}$ & $\begin{array}{l}\text { Causing water borne } \\
\text { diseases }\end{array}$ & $\begin{array}{l}\text { Discolor of cloths and } \\
\text { water tanks }\end{array}$ & $\begin{array}{l}\text { Corrosion } \\
\text { water pipe }\end{array}$ \\
\hline \multicolumn{3}{|c|}{ Existence of Iron } \\
\hline Problem & \multicolumn{3}{|c|}{} \\
\hline \multicolumn{2}{|c|}{ Existence of iron layer in ground water } & Dissolve of iron in the ground water \\
\hline Cause &
\end{tabular}

\section{Cause Effect Diagram; Problem: 03}

Figure 3: Cause effect diagram of different problems.

\section{Solution through the community (Dream Map)}

Dream map is used to depict the future in line with the ambitions of local people. A dream map can be convenient for arriving at the dreams aspirations, feelings of deprivation and the perspective of the local people about their own development, understanding the risks, vulnerabilities, strengths, etc., of the local people, arriving at the areas where people want change [1]. Generally, dream map is Consist of two maps where one representing the present situation and another projecting the desired future. These two maps are drawn by the participants. First, they discuss their existing situation and problem and solution. They started with the present map of the village, which helped them to identify the areas where they would like to change. Then they draw dream map of the areas which represent the future situation of that community. It helps to identify the gaps between the present map and the dream map (Figure 4). From the above map, it is found that, though there exist five tube wells, three of them are usable. For this, Pressure is created during collecting water. There exist only 2 water supply taps but as the presence of iron in the supply water, water from it cannot be used for drinking purpose. The desired map wanted by the people of the 
community are given in the right side of the figure near the existing map. In the desired map, it is found that people show interest to keep pond for washing purpose. They want additional 2 tube wells in the locality. They want well-connected drainage network to solve waterlogging problem. To improve accessibility, they want the existing road network being widened. They also dream of better coordination among the different organization regarding this issue (Figure 4).

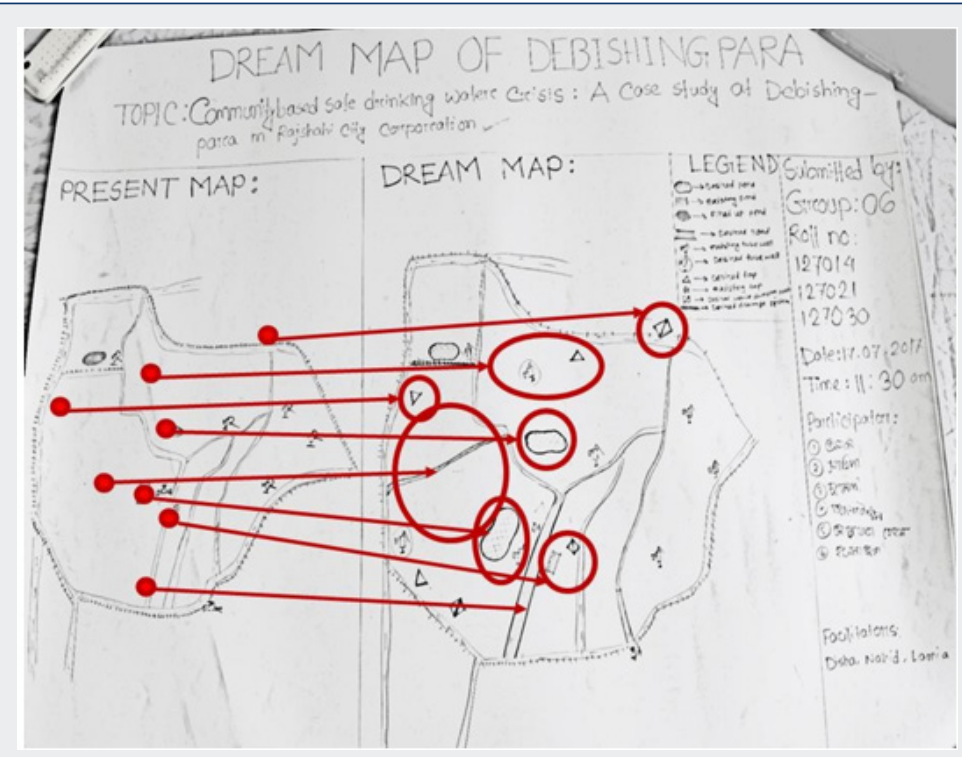

Figure 4: Dream map.

\section{Adaptable policy and strategy for ensuring safe drinking water in the community}

Major Barind Tract challenges are basically groundwater recovery during wet season. Yet heavy abstraction is done from groundwater source for both domestic and irrigation purposes. Quality of supplied water has not been given due attention though it is not good due to the presence of iron, manganese in excess amount. Surface water source and rain water storage are not focused in the area. Drinking water is the constitutional responsibility of the provincial governments. Therefore, this policy framework is intended to guide and support the provincial and district governments in discharging their responsibility in this regard. The functions of the water supply and sanitation sector in Bangladesh is guided primarily by the following important policies and strategies-

a) National Policy for Safe Water Supply \& Sanitation (NPSWSS), 1998.

b) National Policy for Arsenic Mitigation \& Implementation Plan, 2004 (NAMIP).

c) National Sanitation Strategy (NSS), 2005.

d) Pro-Poor Strategy for Water and Sanitation Sector (PPSWSS), 2005.

e) National Sector Development Programme (SDP) for Water Supply and Sanitation, 2010.

The NPSWSS 1998 is the most significant policy which mentions that the national goal is to ensure that all people access to safe water and sanitation services at an affordable cost and aims to increase the capacity of the sector. (Government of People's Republic Bangladesh (2011). National Strategy for Water and Sanitation Hard to Reach Areas of Bangladesh). As the reason behind water scarcity in Debishingpara is more similar to the problem of safe drinking water crisis in Barind areas.

\section{Strategies for Sustainable Solution}

a) Subsurface rainwater recharge, excavation, regeneration and protection of rain fed pond excavated of dried up canals and streams, large storage of surface and rain waters for lean period are possible options that need immediate attention and studies for developing a sound multisource water management system for Barind areas.

b) Attention is also needed to balanced use of groundwater and surface water with greater emphasis on rain water capture and storage.

c) Rigorous campaigns are needed to enlighten people of the benefits of water conservation, use of surface and rain water and eco-sanitation.

Strategy for Immediate Solution: Community water points with appropriate treatment units as needed (arsenic, iron removal of groundwater, filtration of surface water, disinfecting rainwater) may be considered in Hard to Reach (HTR) villages for immediate application.

a) Development, Decision and Ownership-The Community and LGI, e.g., Upazila/Union Parishad. 
b) Design and Implementation -Local Authority, BWDB, Barind Authority, DPHE and NGOs.

\section{Community water enterprise}

This include an implementation process chart flow of household demand-based strategy (Mehdi Azam, T. S [4]. Basically, the adoption of the strategies can be supportive to overwhelm the problems of safe drinking water crisis. The application of the policies can assimilate the discomfort of drinking water crisis of the inhabitants of the area. The coordination between government organizations and NGOs can help to ensure the safe drinking water to every households in the community (Figure 5).

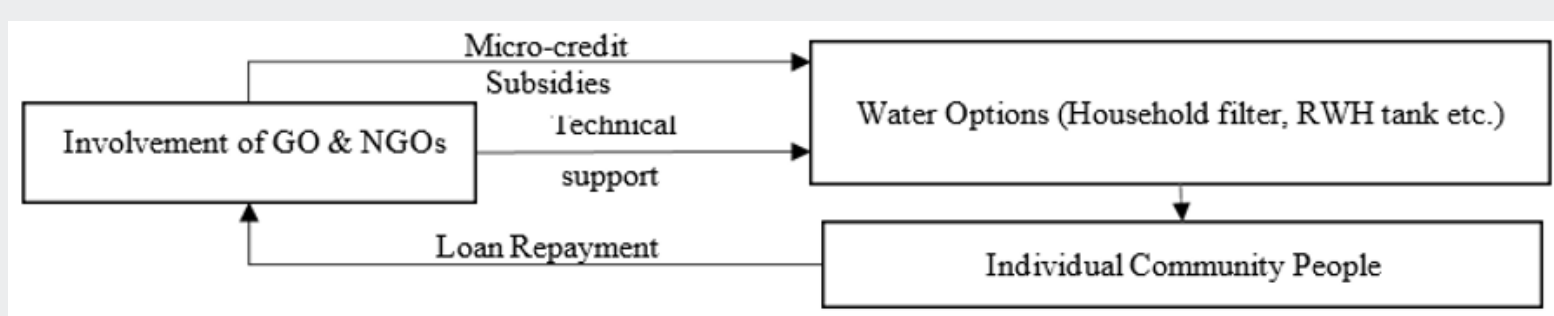

Figure 5: Flow chart of household demand-based strategy.

\section{Conclusion}

Now a day, it has become crying need to have safe drinking water in the study area "Debishingpara". From the above study, about seven problems have been identified regarding safe drinking water crisis and they are- less number of tube well, existence of iron in water, lack of water purification system, high elevated land, ground water depletion in the area, narrow road, and high population density. Comparing among these problems through pair-wise ranking major three problems are found and gradually they are- lack of water purification system, less number of tube well \& existence of iron in water. The cause \& effects of the three major problems have been also identified using cause-effect diagram. The causes are like- financial problem, lack of awareness, problem in sinking tube-well, existence of iron layer in ground water etc. The effects are like - unable in domestic uses, worsening health condition, causing water borne diseases, overcrowded water collection point in the peak hour etc. The study tried out to find desired solution from the focus group members through the dream map. To give solution to these problems some government policies has been recommended. Every citizen deserves to have safe drinking water for a healthy life and the responsibility to establish the right solely rest upon the government.

\section{Acknowledgement}

We, the authors like to thanks to all those persons who spent their valuable time $\&$ helped us in collecting our information, also to all the members of this group who worked hard and gave constant support. We are also grateful to Mahbub Alam, assistance engineer (WASA) for his kind information. Special thanks to the People of Debishing para in Rajshahi specially Alauddin, Tofael Ahmed and Shahida, for their support during PRA.

\section{References}

1. Agnimitra N (2017) Module26-Community Assessment Process and Methods II.

2. Bangladesh Bureau of Statistics (BBS) (1993) Bangladesh Population Census 1991, Zila, Rajshahi. Dhaka, Bangladesh, Government of the People's Republic of Bangladesh.

3. Bangladesh Bureau of Statistics (BBS) (2005b) Population Census-2001, Zila Series, Zila, Rajshahi, Dhaka, Bangladesh, Planning Division, Ministry of Planning. Government of the People's Republic of Bangladesh. Bangladesh's water and sanitation crisis.

4. Mehdi Azam, TS (2013) Adaptation Strategies for Safe Drinking Water Supply in the Low Lying Coastal Regions in Bangladesh. Asian Journal of Environment and Disaster Management 4(3).

5. Rajshahi Development Authority (RDA) (2004) Rajshahi Metropolitan Development Plan 2004-2024. Volume-I Structure Plan and Master Plan. Prepared by RDA under the Ministry of Housing and Public Works, Government of the People's Republic of Bangladesh. Rajshahi Development Authority (RDA). 
CC This work is licensed under Creative

Commons Attribution 4.0 License

DOI: 10.32474 /TCEIA.2018.02.000144

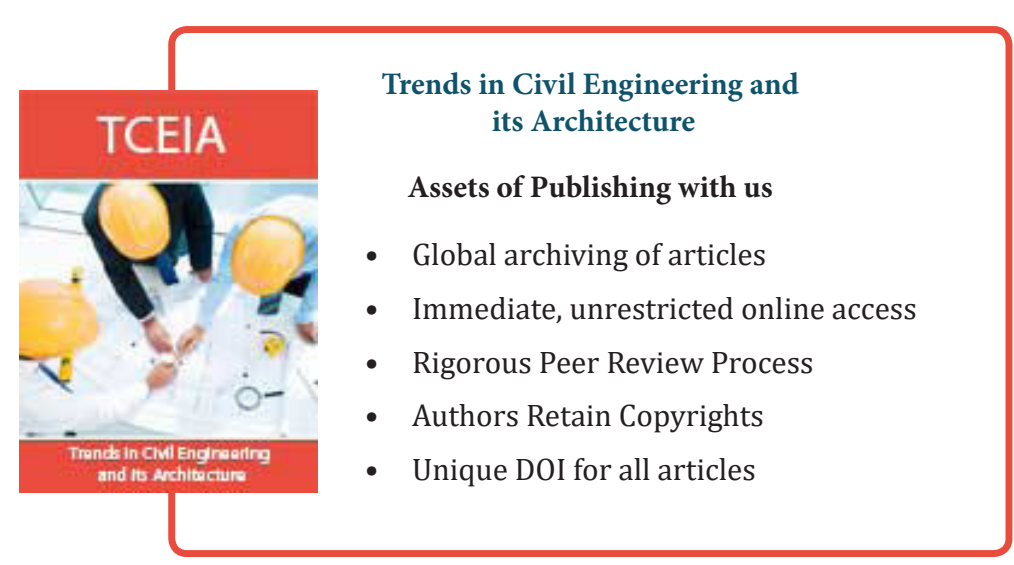

